\title{
Sub-National Constitutional Review System and the Basic Rules of Fair Trial in Ethiopia: The Case of Oromia and Tigray Regional States
}

\author{
Muluken Kassahun Amid \\ Assistant Professor of Law, School of Law, Mettu University, Mettu, Ethiopia
}

\begin{abstract}
Ethiopia has ratified several human rights instruments that guarantee the right to fair trial. The federal and regional government organs in the country are bound by the provisions of these instruments. This article examines the compatibility of the constitutional review systems in Oromia and Tigray Regional States with the basic rules of fair trial such as the right to a public hearing before a competent, independent and impartial court or tribunal. Both Oromia and Tigray Regional States empower their respective Constitutional Interpretation Commissions (CIC) and Councils of Constitutional Inquiry (CCI) to entertain constitutional disputes. Each organ in both regional states is characterized by a centralized non-judicial model of review system. There are several factors that make each reviewing institution less compatible with the elements of basic rules of fair trial. A careful redesigning of the institutions and recognizing the guarantees of relevant human right instruments adopted by the country is primarily recommended.
\end{abstract}

Keywords: Fair Trial, Tigray, Oromia, CIC, CCI, Human Rights Instruments

DOI: $10.7176 / \mathrm{JCSD} / 53-02$

Publication date: November $30^{\text {th }} 2019$

\section{INTRODUCTION}

The right to a fair trial is one of the most important fundamental human rights. The right to fair trial is a right emanating from the principles of the rule of lawupon which a democratic society is built. It plays a paramount role in the judiciary for the administration of justice. Its application sees how the government is treating its citizens. The guarantees of fair trial should be "practical and effective [and] not theoretical and illusory."

Constitutional review bodies are among the organs of government established with the aim of ensuring the supremacy of the constitution, adapting the constitution to the changing realities (living constitution), and enforcing of human rights provisions. ${ }^{2}$ Constitutions put limitations on politics and constitutional adjudication exists in order to enforce these restrictions. ${ }^{3}$ In countries with a federal arrangement and with state constitutions, different methods of state constitutional review systems are adopted. ${ }^{4}$ In Ethiopia, the regional states, including Oromia and Tigray, entrust the function of interpreting regional constitutions to the regional Constitutional Interpretation Commissions (hereinafter CIC) and Councils of Constitutional Inquiry (hereinafter $\mathrm{CCI}) .{ }^{5}$ Accordingly, any regional constitutional dispute ${ }^{6}$, including the provisionof fundamental human rights and freedoms, shall be decided by CIC which is composed of representatives selected by and from the political organs of local governments. The CCI is empowered to screen, investigate, and submit its recommendation to CIC where any law issued by the regional state organs is contested on grounds of constitutionality. Oromia and Tigray Regional States are the first among the Regional States toenact laws that establish and regulate each region's CIC and CCI.

Ethiopia has ratified international and regional human rights instruments that guarantee the right to fair trial such as International Covenants on Civil and Political Rights (ICCPR), and the African Charter on Human and Peoples' Rights (ACHPR). These instruments are integral part of the law of the land. ${ }^{7}$ Both the federal and regional

\footnotetext{
${ }^{1}$ Nuala Mole and Catharina Harby, The right to a fair trial; A guide to the implementation of Article 6 of the European Convention on Human Rights, (Directorate General of Human Rights), $2^{\text {nd }} e d$ 2006, at 7.

${ }^{2} \mathrm{Jim}$ Rossi, 'Assessing the State of the State Constitutionalism', 109 Michigan Law Review, 1148 (2011).

${ }^{3}$ Dieter Grimm, 'Constitutional Adjudication and Constitutional Interpretation: Between Law and Politics', 15 Nujs Law Review, 18 (2011).

${ }^{4}$ For instance, the federal states constitutional review in Germany and Russia entrust to Lander/States Constitutional Court, in the USA by state regular courts and in Switzerland the task is performed by Federal High Court. (Anne Twomey, The Involvement of Sub-national Entities in Direct and Indirect Constitutional Amendment within Federations), retrieved from http://camlaw.rutgers.edu/statecon/workshop11greece07/ workshop11/ Twomey.pdf., last visited on 8 December, 2017.

${ }^{5}$ Christophe Van der Beken, Sub-national Constitutional Autonomy in Ethiopia: On the Road to Distinctive Regional Constitutions (Paper Submitted to Workshop 2: Sub-national Constitutions in Federal and Quasi-Federal constitutional states), retrieved from https://www.jus.uio.no/english/research/news-and-events/ events/conferences /2014/wccl-cmdc/wccl/papers/ws2/w2-vanderbeken.pdf, last visited on 16 July, 2017.

${ }^{6}$ There are debates among scholars on the FDRE Constitution on the key terms of what is "Constitutional dispute", "Constitutional adjudication", "Constitutional interpretation", and so on. The same problem is observed in regional Constitutions since the above terms are largely reproduced from the Federal Constitution. However, this article is not intended to analyze these arguments; rather it employs each term interchangeably to refer constitutional review.

${ }^{7}$ The Federal Democratic Republic of Ethiopia Constitution, Art. 9(4) Federal Negarit Gazette(NO. 1/1995) (Hereinafter, FDRE Constitution).
} 
constitutions also mandate government organs to interpret the fundamental human rights enshrined in the regional state constitutions in conforming to those human rights standards. ${ }^{1}$ The main objective of this article is to analyze the compatibility of the legal and institutional frameworks of the CCI and CIC systemsin Oromia and Tigray Regional States. The article focuses on the elements of the basic rules of fair trial guarantees particularly the right to equality before courts and tribunals, fair and public hearing by a competent, independent and impartial tribunal. For this purpose, the article principally relied on critically analyzing legal instruments and literature. Comparative analysis has been made where necessary.

The article is organized into five sections. Section one is an overview of the constitutional review design in the Regional States of Ethiopia. In section two, the article deals with the right to fair trial guarantee in different human rights instruments. The component elements and applicability of such elements to constitutional adjudication organs are critically analyzed. Section three assesses the applicability of basic rules of fair trial rights in the federal states, in general, and in Tigray and Oromia constitutional review systems, in particular. In section four, the current constitutional review system in Oromia and Tigray is examined in light of thesebasic elements of the right to fair trial. Finally, the paper wraps up by providingconcluding remarks.

\section{OVERVIEW OF THE CONSTITUTIONAL REVIEW DESIGN IN ETHIOPIAN REGIONAL STATES}

In Ethiopia, regional states were officially established for the first time during the Transitional period (1991-1995) under Proclamation No.7/1992. ${ }^{2}$ This Proclamation empowers regional self-governments to issue regional constitutions. $^{3}$ To this effect, several states adopted their own transitional period constitution including Tigray (then Region One) and Oromia (then Region Four). During the transitional period, the Oromia Constitution empowered the Regional Supreme Court to interpret the constitution. ${ }^{4}$ The Tigray Constitution, on the other hand, was silent regarding the interpretation of the constitution.

Later, the 1995 FDRE Constitution empowered regional states to enact their own constitutions through their State Councils (the regional legislatures). ${ }^{5}$ If the law enacted by State Councils is contested as unconstitutional under the FDRE Constitution, the Federal CCI considers the matter and submits it to the House of Federation (HOF) for a final decision. ${ }^{6}$ Though the Constitution is silent on the body and the procedure to interpret state constitutions in the event of state laws, acts and decisions of government organs are challenged as unconstitutional. Each regional state in their earlier constitutions entrusted the power to interpret their Constitutions to the State Council, the body that adopted the Constitution. ${ }^{7}$

Since the 2001 constitutional revision in all states, the power to interpret the Constitution is entrusted to CIC except Southern Nations, Nationalities and Peoples Regional State (SNNPRS). The SNNPRS Constitution entrusts such power to the regional upper house called the Council of Nationalities (CON) which was designed based on the federal HOF model. ${ }^{8}$ Each region develops a diversified mechanism in the selection and composition of members of each organ. ${ }^{9}$ All Regional States' constitutional interpretation organs share the common features of the

${ }^{1}$ Id, Art. 13(1 and 2). Similar provisions also provided in Regional States Constitutions (See Art. 13 of the Tigray, Amhara, Oromia, SNNPRS and Harari Regional States Constitutions as well as Art. 14 of the Gambela, Benishangul, Afar and Somali Regional States Constitutions). ${ }^{2}$ A Proclamation that Provides for the Establishment of National/Regional Self Government, Negarit Gazeta, Art. 3 (NO.7/1992). ${ }^{3} I d$, Art. 15(1A)

${ }^{4}$ The Oromian National Self-Government Constitution, Art. 51, Magalata Oromia, (NO. 2/1993)

${ }^{5}$ FDRE Constitution, Supra note 7, Art. 50(5) and 52(2b).

${ }^{6} I d$, Art. 84(2)

${ }^{7}$ Tsegaye Regassa, 'Sub-National Constitutions in Ethiopia: Towards Entrenching Constitutionalism at State Level', 3 Mizan Law Review, 42 (2009). The rationale of the drafters of the Oromia Constitution to transfer the power to interpret the regional constitution from regional Supreme Court to State Council was to protect the legislative dignity, which the unelected judges should not quash the laws enacted by elected representatives of the people (directly accountable to the people) and to prevent unwarranted judicial activism. By doing so, the system prevents judicial dictatorship and protects legislative dignity by limiting role of the judiciary only to the power of referral in case of any constitutional disputes arise. (Interview with Melese Abayneh, The Drafting Member of the Oromia CIC and CCI law, and Member of Oromia CCI Legal Expert, (Addis Ababa, Ethiopia, 22 January 2016).

${ }^{8}$ In SNNPRS, the ethnic groups of the region represented in the Council of Nationalities (final constitutional interpreter) by at least one member. Each Nations, Nationalities, and Peoples shall be represented by one additional representative for each one million of its population like the Federal HOF. (See The Revised Constitution Of Southern Nations, Nationalities and Peoples Regional State (SNNPRS), Art. 59(1), Debub Negarit Gazette (NO. 35/2001).

${ }_{9}^{9}$ Accordingly, the Tigray CIC composes one representative from each Woreda/ District Council including Urban Councils, representative of indigenous minorities (namely Irob and Kunama) as well as the representatives of the region in the House of the Federation. Similarly, the Afar CIC composed of representatives of each Woreda Council and representatives of Argoba ethnic group (indigenous minority). Moreover, in Amhara Region, the CIC is composed of members from Woreda Council and Nationality Council (i.e. the assembly of the Nationality Administration). In later case, the Amhara Constitution guaranteed representation of indigenous minority ethnic groups of the region namely the Oromo, Waghimra, Awi, Argoba and Kimant.In Oromia and Somali, the CIC composes one representative nominated by District/Woreda Council including Urban Councils. In both regions, there is no guaranteed representation for ethnic minorities in the regional CIC. The Revised Benishangul-Gumuz Constitution provides that five indigenous ethnic groups of the region (namely Berta, Gumuz, Shinasha, Komo and Mao) are entitled to four representatives in their regional CIC. The Revised Gambella Constitution Art. 74(1)), also, stipulates that the Gambella CIC will be composed of representatives of each Council of Nationalities including Upo and Komo. In Harari Region, the CIC comprises seven members represented from different organs. (Yonatan Tesfaye and Christophe Van der Beken, Ethnic Federalism and 
centralized non-judicial model of constitutional review system. In all regions, the CCI is still serving as an advisory body of each final interpreting organs (CIC and $\mathrm{CON}) .{ }^{1}$ However, there is a difference between the regions in the level of the accommodation of indigenous and non-indigenous ethnic minorities within the regions. ${ }^{2}$ Indigenous minorities have a right to their own sub-regional territorial administration and to a representation in the regional institutions including in the constitutional interpreting organ. However, non-indigenous minorities do not enjoy such specific protection in the region, and they can merely claim individual rights. Indeed in all regions, the constitutional accommodation of ethnic diversity is limited to the majority indigenous groups.

Generally, the constitutional interpretation systems in the Regional States are basically modelled after the federal one. However, in case of the FDRE Constitution, one of the reasons for vesting the power to interpret the constitution in the HOF is that it is composed of the representatives of Nations, Nationalities and Peoples, which the constitution empowers as sources of the sovereign power of the country. The makers and owners of the FDRE Constitution are Nations, Nationalities and Peoples who are represented in the HOF and, hence, the makers and owners of the constitution should as well be the guardians of the same through the HOF. ${ }^{3}$

However, in regions who have more homogeneous groups, namely Tigray, Afar, Amhara, Oromia, and Somali, the dominant ethnic groups are represented from the Woreda Council. In these regions, the logic used to justify the HOF's power cannot be applied since the constitution is not the expression of the sovereignty of Woredas in each state.

\section{THE RIGHT TO FAIR TRIAL IN HUMAN RIGHTS INSTRUMENTS}

Many universal and regional treaties and non-treatiesof human rights instruments guarantee the right to a fair trial. ${ }^{4}$ Among the treatiesthat recognized and enshrined the right to a fair trial are the following. Art. 14 of the ICCPR $^{5}$, Arts. 2(c) and 15 of the Convention on the Elimination of All Forms of Discrimination against Women, Arts. 2 and 5 of the International Convention on the Elimination of All Forms of Racial Discrimination, Arts. 12 and 13 of the Convention on the Rights of Persons with Disabilities, Art. 40(2b) of the Convention on the Rights of the Child, Art. 18(1) of the Convention on the Protection of the Rights of All Migrant Workers and Members of their Families, Arts. 7 and 26 of the ACHPR, Art. 6 of the European Convention for the Protection of Human Rights and Fundamental Freedoms (ECHR), Art. 47 of the Charter of Fundamental Rights of the European Union, Arts. 12 and 13 of the Arab Charter on Human Rights and Arts. 8 and 27 of American Convention on Human Rights clearly stipulated a guarantee on the right for a fair trial. ${ }^{6}$

Among non-treaty human right instruments that guaranteed the right to fair trial with diversified component elements ${ }^{7}$ are the following. Art. 10 of the Universal Declaration of Human Rights, Art. 9(2) of Declaration on the Right and Responsibility of Individuals, Groups and Organs of Society to Promote and Protect Universally Recognized Human Rights and Fundamental Freedoms, The Bangalore Principles of Judicial Conduct, The Burgh House Principles on the Independence of the International Judiciary, The Principles on Fair Trial in Africa, The Beijing Statement of Principles on the Independence of the Judiciary in the LAWASIA Region, Latimer House Guidelines for the Commonwealth on Parliamentary Supremacy and Judicial Independence, Commonwealth Principles on the Accountability of and the Relationship between the Three Branches of Government, Art. XXVI of the American Declaration of the Rights and Duties of Man, Art. 67 of the Rome Statute of the International

Internal Minorities: The Legal Protection of Internal Minorities in Ethiopia, 21(1) African Journal of International And Comparative Law, 40(2013).

${ }^{1}$ The composition and powers of all regional CCI are copied from the Federal CCI. In all regions, the body is composed of eleven members from the three arms of regional government during their selection. The President and Vice-President of the Regional Supreme Court from the Judiciary will act as Chairperson and Vice-Chairperson of the CCI respectively. Furthermore, there are six legal experts appointed by the State Council upon the recommendation of the regional President, which implies their selection involves the legislature and the executive. The remaining three members of the CCI are designated by the State Council whom the speaker shall submit for approval. Exceptionally, in the SNNPRS the three persons are designated by the Speaker of the Council of Nationalities (CON) from its members.

${ }^{2}$ Indigenous minorities are those ethnic groups that have traditionally lived in the territory of the region. The non-indigenous groups are considered to be those groups that have migrated to the region in a more recent past and that are indigenous to another region. (Christophe van der Beken, Federalism, Local Government and Minority Protection in Ethiopia: Opportunities and Challenges, Journal of African Law, 7(2014), available on CJO 2014 doi:10.1017/S00218 55314000205).

${ }^{3}$ Teferi Bekele, Human Rights Protection under the FDRE and the Oromia Constitutions: A Comparative Study, 5 Oromia Law Journal, 56(2016).

${ }^{4}$ Treaty provisions are legally binding on the states that are parties to the treaty. The instruments called Covenant, Convention, Charter and Protocol are treaties. While non-treaty instruments are not in themselves binding, they represent the consensus of the international community on standards to which states should conform. Non-treaty instruments are usually called Declarations, Principles, Rules, and Guidelines and so on. (Amnesty International, Fair Trial Manual 2-3 (2 ${ }^{\text {nd }}$ ed., Amnesty International Publications, 2014).

${ }^{5}$ Art. 14 of the Covenant composes seven paragraphs; para.1 guarantees equality before courts, fair and public hearing by a competent, independent and impartial tribunal, and paras. 2-7 deals with procedural and substantive guarantees to persons charged with a criminal violation. The United Nations Human Rights Committee (UNHRC) adopts a General Comment No. 32 on Art.14, which replaces the former General Comment No. 13.

${ }^{6}$ Amnesty International,Supra note 20, at 103-122.

${ }^{7} I d$; International Principles on the Independence and Accountability of Judges, Lawyers and Prosecutors, Practitioners Guide No. 1, 79-226 $\left(2^{\text {nd }} \mathrm{ed}\right.$. International Commission of Jurists, 2007). 
Criminal Court. Art. 20 of the Statute of the International Criminal Tribunal for Rwanda andArt. 21 of the Statute of the International Criminal Tribunal for the former Yugoslavia and so on.

\subsection{The Component Elements of the Basic Rules of the Right to Fair Trial}

The right to fair trial is usually classified into three parts: basic rules, minimum guarantees and other provisions. ${ }^{1}$ The basic rules of the right to a fair trial consists of the right to be equal before the courts, the right to a fair and public hearing by a competent, independent and impartial tribunal established by law, and the right to be presumed innocent. ${ }^{2}$ Accordingly, the right to equality before courts and tribunals and to a fair trial are key elements of human rights protection and serve as the procedural means to safeguard the rule of law. ${ }^{3}$ It includes the right to equality before the law and equal protection of the law, equality before the courts and equal treatment by the courts, and equal access to the courts. These rights apply regardless of the nature of proceedings before such bodies that are available to all citizens and non-citizens of a country irrespective of their identity and status. ${ }^{4}$

States are also encouraged to provide free legal aid for individuals depending on two conditions. ${ }^{5}$ First, the person concerned does not have sufficient means to pay for the legal assistance, and second, 'the interests of justice'require that legal counsel be assigned to represent a person. ${ }^{6}$ It may also depend on an accused's particular vulnerabilities due to factors such as age, health, disability or economic or social disadvantages. In addition, the imposition of fees on the parties to the judicial proceedings amounts to de facto prevent their access to justice.

The competence, independence and impartiality of a tribunal are the basic requirementsfor the right to fair trial. The right is recognized in treaties and non-treaty standards and has developed into customary international law. Therefore, those countries that have not acceded to or ratified the treaties are still bound to respect this right and arrange their judicial systems accordingly. ${ }^{8}$ Besides, the UN Human Rights Committee notes that the requirement is absolute and the right to fair trial is not subject to any exception or derogation. ${ }^{9}$ The African Commission on Human and Peoples' Rights also notes, 'the right should be considered non-derogable' since it provides a 'minimum protection to citizens'. ${ }^{10}$

In this regard, the right to a fair hearing involves the requirements of the competence of individual judicial officers (qualified and experienced persons to act as judicial officers), the competence of a tribunal to make a binding decision and jurisdictional competence of a tribunal. ${ }^{11}$ The objective of these requirements is to ensure that each tribunal is capable to decide on matters brought before it. Moreover, the requisite of independence refers to personal, institutional and decisional aspects. Personally, the independence and the status of judicial officers/judges, including procedure of appointment and removal, guarantees relating to their security of tenure until a mandatory retirement age or the expiry of their term of office, adequate remuneration, conditions of service, and pensions shall be adequately secured by law. ${ }^{12}$ Judges may be dismissed only on serious grounds of misconduct or incompetence in accordance with fair procedures. The dismissal of judges by the executive without any specific reasons given to them and without effective judicial protection being available to contest the dismissal is incompatible with the independence of the judiciary. ${ }^{13}$

Institutionally, the judiciary should be independent from political interference by the executive and legislative branch. ${ }^{14}$ It is incompatible with the notion of the independence of the judiciary when there is a situation where the functions and competencies of the judiciary and the executive are not clearly distinguishable or where the latter is able to control or direct the former. In the decision-making aspects of independence, the existence of adequate

\footnotetext{
${ }^{1}$ Jixi Zhang, 'Fair Trial Rights in ICCPR', 2(4) Journal of Politics and Law. 39 (2009).

${ }^{2}$ While the minimum guarantees of fair trial rights comprises the elements of the right to be informed of the charge, the right to prepare defence and to communicate with counsel, the right to be tried without undue delay, the right to be present during trial, to defend and to legal assistance, the right to call and examine witnesses, the right to the free assistance of an interpreter, and the privilege against self-incrimination. The miscellaneous guarantees of fair trial include the special guarantees for juvenile persons, the right to appeal, the right to compensation for wrongful conviction, the right against second trial for the same offence, and the right not to be held guilty for an act or omission not constituting a criminal offence. (id).

${ }^{3}$ UN Human Rights Committee, General Comment No. 32, Art. 14: 'Right to equality before courts and tribunals and to a fair trial', para. 2 , U.N. Doc.CCPR/C/GC/32 (2007), retrieved from https://www1.umn.edu/humanrts/gencomm/hrcom32.html., last visited on 11 April, 2016. ${ }^{4} I d$, paras. $7-9,13$

${ }^{5} I d$, para. 10 .

${ }^{6}$ In order to determine whether the 'interests of justice' require that the Court will have regard to various criteria, including: the gravity of the offence and of the possible sanction;the capacity of the defendant to represent her/himself;and the complexity of the case. (Legal Digest of International Fair Trial Rights, Published by the OSCE Office for Democratic Institutions and Human Rights (ODIHR), 2012 , at. 147.

${ }^{7}$ General Comment No. 32 Supra note 26, para. 11. The UN Human Rights Committee has also noted that the right of access is not absolute and that it is permissible to impose reasonable fees, or deposits, where this is rationally linked to ensuring the proper administration of justice. (Casanovas v France, HRC Communication 1514/2006, UN Doc CCPR/C/94/D/1514/2006 (2008), para 11.3).

${ }^{8}$ Amnesty International, Supra note 20 at xvii, International Commission of Jurists, Supra note 23, at 8.

${ }^{9}$ General Comment No. 32, Supra note 26, para. 19

${ }^{10}$ International Commission of Jurists, Supra note 23, at 6

${ }^{11}$ OSCE/ODIHR, Supra note 29, at.56-61.

${ }^{12}$ General Comment No. 32, Supra note 26, para. 19.

${ }^{13} I d$, para. 20.

${ }^{14} \mathrm{Id}$.
} 
guarantees protecting the tribunal and its members from external pressures determines whether a body can be considered to be independent. It is also necessary to protect judicial officers/judges against conflicts of interest and intimidation. ${ }^{1}$

The criterion of impartiality, which is related to decisional independence, has two main features. First, judges must not allow their judgment to be influenced by personal bias or prejudice, nor must they harbour preconceptions about the particular case before them, nor act in ways that improperly promote the interests of one of the parties to the detriment of the other (subjective/actual impartiality). Second, the tribunal must also appear to a reasonable observer to be impartial (objective/apparent impartiality). ${ }^{2}$ Thus, a trial will be unfair not only if the judge/ judicial officer is not impartial but also if he or she is not perceived to be impartial. ${ }^{3}$ This implies the legal safeguards of the independence and impartiality of the judiciary may not be sufficient. The safeguards must be effectively incorporated and reflected in the everyday attitudes and practices of actors in both the judicial and executive branches.

In relation to the guarantee of fairness of a hearing, the proceeding entails the absence of any direct or indirect influence, pressure or intimidation or intrusion from whatever side and for whatever motive. ${ }^{4}$ Expeditiousness is also an important aspect of the fairness of the hearing. Undue delays in criminal and in civil proceedings undermine the principle of fair hearing unless the delays cannot be justified by the complexity of the case or the behaviour of the parties. As such delays may be caused by lack of resources or under-funding, an appropriate budget should be allocated for the administration of justice. ${ }^{5}$

A public hearing is also a requirement and there should be meaningful opportunities for members ofthe public to attend the hearing. The conduct of hearings in public helps to ensure the transparency and integrity of the judicial process. Information about the time and location must be made available to the public by the courts. In addition, the courts must provide adequate facilities, within reasonable time limits, for the attendance of interested members of the public.

However, the right to a public hearing is a qualified right. Human rights instruments acknowledge that courts have the power to exclude all or part of the public for reasons of morals and public order, national security in a democratic society, when the interest of the private lives of the parties so requires, or to the extent strictly necessary in the opinion of the court in special circumstances where publicity would be prejudicial to the interests of justice. ${ }^{6}$ Apart from the formal exclusion of the public from a hearing, there may be other practical factors that may result in the de facto exclusion of the public from a hearing such as lack of publicity of hearings, an inaccessible venue, insufficient courtroom space or the application of unreasonable conditions on entry into the courtroom. Such practical hindrances to the enjoyment of rights may lead to the circumvention of the human right to public hearing. ${ }^{7}$

\subsection{Applicability of the Basic Rules of Fair Trial Guarantees to Constitutional Adjudication Bodies}

Human rights instruments do not clearly state the applicability of the right to fair trial guarantees on constitutional reviewing organs. Hence, it is primarily important to deal with whether the constitutional adjudicating bodies considered as tribunals. The UN Human Rights Committee defined the notion of a tribunal as

a body, regardless of its denomination, which is established by law, is independent of the executive and the legislative branches of government or enjoys in specific cases judicial independence in deciding legal matters in proceedings that are judicial in nature. ${ }^{8}$

In order to determine whether a certain body qualifies as a tribunal, we should focus on three elements: First, it has to be guaranteed that the tribunal is one established by law. Second, the tribunal is competent to decide on matters brought before it. Third, the tribunal is both independent and impartial.The notion of a tribunal generally includes the ordinary courts. ${ }^{9}$

When examined in light of the above parameters, constitutional review bodies fulfil the requirements. The establishment, power and function of such bodies is usually enumerated in the national constitutions of countries. In relation to the competence of the review bodies, the persons to act as constitutional adjudicatorare required to be suitably qualified and experienced. The decisions of the review bodies are binding and have the capacity to nullify unconstitutional provisions of the law.

In relation to the jurisdictional competence of constitutional reviewing bodies, they entertain cases involving

\footnotetext{
${ }^{1}$ Id.

${ }^{2}$ Karttunen vs. Finland, Communication, No. 387/1989, U.N. Doc. CCPR/C/46/D/387/1989 (1992), para. 7.2, retrieved from http://www1.umn.edu/humanrts/undocs/html/dec387.htm, last visited on 7 April 2016.

${ }^{3}$ The Constitutional Rights Project v. Nigeria, African Commission on Human and Peoples' Rights, Communication No. 87/93 (1995), paras. $13-14$.

${ }^{4}$ General Comment No. 32, Supra note 26, para. 25.

${ }^{5} \mathrm{Id}$.

${ }^{6}$ See, for instance, Art. 14(1) of the ICCPR, Art. 6(1) of ECHR, and Section A(3)(f(i-ii)) of the Principles on Fair Trial in Africa.

Amnesty International,Supra note 20, at 123 .

${ }^{8}$ General Comment No. 32, Supra note 26, para. 18.

${ }^{9}$ OSCE/ODIHR, Supra note 29, at 54-56.
} 
issues of constitutionality of laws/acts of legislative and executive bodies as well as other cases requiring the interpretation of constitutional provisions. Constitutional review bodies have a wider jurisdiction than ordinary courts as they are empowered to entertain abstract and political questions.

The independence and impartiality of constitutional review organs is practiced in different ways in diffused and centralized model review systems. In the diffused system, ordinary courts interpret constitutionality of acts. Hence, it is obvious that the elements of basic rules of trial are applicable in this system of review by ordinary courts. However, the ordinary courts cannot entertain all issues of constitutionality to minimize active involvement in the competence of the legislative and executive branches. ${ }^{1}$ To this effect, the USA Supreme Court has developed self-restraining doctrines so thatthe only constitutional issues entertained by the courts are those incidental to concrete real cases.

In countries adopting the centralized model review system, the functions of constitutional review organs have apparent judicial and political characters. ${ }^{2}$ Politicians are involved during the selection process of judges of constitutional court and that is the stage where they have the chance to promote their political interest. ${ }^{3}$ However, the constitutional courts should be independent of any other organ in order to ensure the effective control of other organs. Once judges are elected, they retain and demonstrate their independence. Their decisions must be grounded on the dictates of the Constitution and their independence and impartiality should be guaranteed by their status and by the procedures prescribed by the law. ${ }^{4}$ Generally, constitutional review organs for all practical purposes and intents constitute a tribunal.

The organs are seen as tribunals under the authoritative guidance to interpreting treaties dealing with fair trial rights. ${ }^{5}$ The guidance stresses on the applicability of basic rules of fair trial guarantees on constitutional review organs. The UN Human Rights Committee puts emphasis on this point:'the provisions of Art. 14 apply to all courts and tribunals within the scope of that article whether ordinary or specialized, civilian or military. ${ }^{6}$ The clause does not make exceptions to constitutional adjudicating bodies and covers the specialized Constitutional courts in those countries following the centralized constitutional review model. ${ }^{7}$ It is also to be noted that the applicability of the basic rules of fair trial does not depend on the nature and level of the institution. ${ }^{8}$ Every tribunal including constitutional review organs is to be guided by the standards. ${ }^{9}$

The criteria of competence, independence, and impartiality of a tribunal are absolute requirements not subject to any exception. There can't be a general reservation to the right to a fair trial as this would be incompatible with the object and purpose of the human right standards. ${ }^{10}$ In Gonzalez del Rio vs. Peru, the UN Human Rights Committee decided that the domestic courts (including Constitutional Court) were not impartial and independent in dealing with the claimant's case. ${ }^{11}$ Similarly, in Oló Bahamonde vs. Equatorial Guinea, the Committee ruled that the claimant was not required to exhaust domestic remedies since there are no effective domestic remedies to exhaust or even pursue due to the absence of an independent judiciary. ${ }^{12}$

The Human Rights Committee also expressed concerns that judges of the Constitutional and Supreme Courts in Belarus could be dismissed by the President of the Republic without any safeguards following an allegation that the President had dismissed two judges for failing to collect a fine imposed by the executive. ${ }^{13}$ The domestic judicial bodies including constitutional review organs are not independent in performing their tasks if they can be removed by the executive branch of government; In other words, the above discussed scenarios show the applicability of the requirement of basic rules of fair trial for constitutional review organs irrespective of how they are set up by domestic laws of the member states.

${ }^{1}$ Assefa Fisseha, 'Constitutional Adjudication in Ethiopia: Exploring the Experience of HOF', 1 Mizan Law Review, 7-8(2007).

${ }^{2}$ Rudolf Streinz, 'The Role of the German Federal Constitutional Court Law and Politics',31Ritsumeikan Law Review 96(2014).

${ }^{3}$ Id.

${ }^{4} I d$.

${ }^{5}$ The authoritative guidance to interpreting treaties is provided by the General Comments, General Recommendations, Reports, Concluding Observations, Findings, Decisions and Judgments of treaty monitoring bodies and human rights courts. (Amnesty International, Supra note 20 at 2).

${ }^{6}$ General Comment No. 32, Supra note 26, para.22

${ }^{7}$ Lawyers Committee for Human Rights, What is A Fair Trial? A Basic Guide to Legal Standards and Practice, 2000 ,at 7.

${ }^{8}$ The concept of a 'suit at law' according to the UN Human Rights Committee includes

(a) judicial procedures aimed at determining rights and obligations pertaining to the areas of contract, property and torts in the area of private law, (b) equivalent notions in the area of administrative law such as the termination of employment of civil servants for other than disciplinary reasons, the determination of social security benefits or the pension rights of soldiers or procedures regarding the use of public land or the taking of private property and it may also (c) cover other procedures which, however, must be assessed ${ }^{9} I d$, para. 18 on a case by case basis in the light of the nature of the right in question" (General Comment No. 32, Supra note 26, para.16).

${ }^{10} I d$, Para. 5 \& 19

${ }^{11}$ Gonzalez del Rio vs. Peru, Communication No. 263/1987, U.N. Doc. CCPR/C/46/D/263/1987 (1992) paras. 2.3, 2.5 and.5.2, retrieved from http://www1.umn.edu/humanrts/undocs/html/dec263.htm, last visited on 7 April 2016.

${ }^{12}$ OlóBahamonde vs. Equatorial Guinea, Communication No. 468/1991,U.N. Doc. CCPR/C/49/D/468/ 1991(1993)paras. 2.3 and 9.4, retrieved from http://www1.umn.edu/humanrts/undocs/html/vws468.htm, last visited on 7 April 2016.

${ }^{13}$ Concluding Observations of the Human Rights Committee, HRC Concluding Observations: Belarus, UN Doc. CCPR/C/79/Add.86 (1997) para. 13. 


\section{BASIC RULES OF RIGHT TO FAIR TRIAL GUARANTEES IN CONSTITUTIONAL REVIEW IN TIGRAY AND OROMIA REGIONAL STATES}

Human rights treaties require State Parties to respect and ensure the enforcement of the rights to fair trial. ${ }^{1}$ There are debates on how international agreements are going to be enforced in the federal states. However, it is argued here that the Ethiopian regional states are under a duty to enforce the human rights instruments ratified by the country.

International law anticipates that federal governments may delegate the implementation of human rights treaty provisions to their sub national entities. In connection with this, several human rights instruments and their authoritative interpretations mandate sub-national governments to implement the provisions. Art.50 of the ICCPR, for example, provides, '[t]he provisions of the present Covenant shall extend to all parts of federal states without any limitations or exceptions.' It then follows that federal states of the ICCPR signatory states have the duty to enforce the provision of the Covenant without any defenses including the state's autonomy or federal comity. The federal government remains internationally responsible for a state's failure to implement treaty obligations. ${ }^{2}$ In a similar manner, The UN Human Rights Committee follows a similar interpretation:

The obligations of the Covenant (ICCPR) in general and Art.2, in particular, are binding on every State Party as a whole. All branches of government (executive, legislative and judicial), and other public or governmental authorities, at whatever level (national, regional or local) are in a position to engage the responsibility of the State Party. ${ }^{3}$

As Ethiopia is a member party of the Covenant, all tiers of government, irrespective of their power and functions, are bound by the provisions of the ICCPR and the General Comments on it.

International human rights are incorporated into Ethiopian legal system through express recognition in the federal and state constitutions as well as other primary and subordinate legislations making international agreements an integral part of the laws of the land upon ratification and interpreting of fundamental rights and freedoms of chapter 3 in conforming to international human rights instruments adopted by the country. ${ }^{4}$ Through ratification and interpretation of domestic laws in conformity with the ratified instruments the country has consented to be governed according to the guidance in the internationally agreed human rights laws. Hence, in the context of Ethiopian Regional States constitutional review, the establishment, structure, composition, power, and function of each organ including the Oromia and Tigray CCI and CIC legal and institutional frameworks should conform to the human rights instruments that guarantee the basic rights to a fair trial.

\section{THE CONSTITUTIONAL REVIEW SYSTEMS IN THE OROMIA AND TIGRAY REGIONAL STATES}

Oromia and Tigray Regional States are among the first regions to enact specific laws that govern Regional States' CIC and CCI. The Oromia Caffee (State Council) established the Oromia Constitutional Interpretation Commission (CIC) and the Council of Constitutional Inquiry (CCI) by Proclamation No. 167/2011 and 168/2011, respectively. Similarly, the Tigray Regional State Council also established the same institutions by Proclamation No. 228/2012 (CIC) and 229/2012(CCI). Those proclamations define the powers and functions of both organs. The organs have started receiving cases in both regions. ${ }^{5}$ Under this section, the article examines CIC and CCI in both Regional States and the compatibility of the legal and institutional frameworks with the basic rules on the right to fair trial.

\subsection{Equality Before Courts and Tribunals}

The right to equality before courts/tribunals applies whenever domestic law entrusts a judicial body with a judicial task including the functions of constitutional interpretation. ${ }^{6}$ In Ethiopia, the federal and regional constitutions stipulate that everyone has the right to bring 'justiciable matter' to any competent body with judicial power. ${ }^{7}$ In this regard, in Tigray and Oromia regional states, the right to access to constitutional reviewing organ is guaranteed to 'any person'. ${ }^{8}$ However, the right is not absolute; it is conditional upon the fulfilment of the requirement of a

\footnotetext{
${ }^{1}$ See Art. 2(1) of the ICCPR, \& Art. 1 of the ACHPR.

${ }^{2}$ Risa E. Kaufman, ' "By Some Other Means”: Considering the Executive's Role in Fostering Sub-national Human Rights Compliance', 33 Cardozo Law Review, 1990 (2012).

${ }^{3}$ UN Human Rights Committee, General Comment No. 31, 'Nature of the General Legal Obligation on States Parties to the Covenant', para. 4 U.N.Doc. CCPR/C/21/Rev.1/Add.13(2004), retrieved from https://www1.umn.edu/humanrts/gencomm/hrcom31.html, last visited on 11 April 2016.

${ }^{4}$ Ibrahim Idris, 'The Structure of Human Rights Regime of The FDRE Constitution: Fundamental Rights and Freedoms',Proceedings of the Symposium on the Role of Courts in the Enforcement of the Constitution(2000).

${ }^{5}$ For instance, the Oromia CIC received about eight cases as of February 2016 including the claim for identity recognition of Zay community. Though, six constitutional complaint cases out of eight are rejected on the ground of period of limitation. (Interview with Mr Abdi Kedir, Senior Legal Expert at Oromia CIC (Addis Ababa, Ethiopia, 28 January 2016).

${ }^{6}$ General Comment No. 32, Supra note 26, para. 7.

${ }^{7}$ For instance, see Art.37 of the FDRE Constitution, Tigray and Oromia Constitutions.

${ }^{8}$ A Proclamation Enacted to Establish Oromia Council of Constitutional Inquiry, Magalata Oromia, Art. 22(1), (NO. 168/2011) (hereinafter,
} 
constitutionality issue arising from a concrete case. ${ }^{1}$

There are also other limitations. One such limitation relates to the composition of the judicial organ. In the case of Tigray and Oromia CIC, there isn't any express guarantee for non-indigenous minorities of the region to be included in the reviewing body. Moreover, the Revised Oromia Constitution provides that the sovereign power of the region belongs only to the Oromo nation. In effect, the composition of Oromia CIC is impliedly reserved for the indigenous ethnic groups of the region. This may result in the deficiency in apparent and actual impartiality, particularly, in cases involving group right claims from non-indigenous ethnic groups such as claims for recognition of identity and the right to self-rule. As a result, such minority groups are likely to prefer to submit their cases to the Federal CCI and HOF.

Besides, as the Woreda and State Council of both regions are fully occupied by ruling party members in the last two elections, the opposition parties have no chance of voting on recommendations and appointments of each $\mathrm{CCI}$ and CIC members. ${ }^{2}$ This makes the institution less accommodating to the diversified political interests in the process of selection of the members.

Both the Tigray and Oromia laws on CCI and CIC donot recognize enforcement provisions of the right to appointed counsel. ${ }^{3}$ In a case on constitutional appeal, the UN Human Rights Committee noted that

where a convicted person seeking constitutional review of irregularities in a criminal trial has insufficient means to meet the costs of legal assistance in order to pursue his constitutional remedy and where the interests of justice so [require], legal assistance should be provided by the State. ${ }^{4}$

In Ethiopia, even though both the federal and regional constitution guarantees the right to get legal representation at state's expense for a person who is unable to pay for it, Tigray and Oromia Regional States' CIC and CCI law doesn't provide for any procedure to enforce such rights.

The Oromia CIC and CCI lawsrequire the payment of service fees without specifying the circumstances under which such payment of service fees is required. ${ }^{5}$ The requirement of service fees may limit the right to equal access to constitutional justice to applicants who do not have sufficient means to pay for it. In this regard, the lesson from Tigray regional state is useful:both the CCI and CIC law expressly exclude the payment of any fee as a condition for filing a constitutional claim. ${ }^{6}$

\subsection{Competence, Independent and Impartial Tribunal}

In order to ensure quality of decision, human rights instruments require certain levels of competence as a condition for membership of an organ with judicial task. Individuals who decide on the issue of constitutionalityare expected to have sufficient knowledge of the law. ${ }^{7}$ Even if the criterion of competence differs from one country to another, almost all of them demand high academic and professional excellence in legal expertise. ${ }^{8}$

The profiles of all the CIC members in both Oromia and Tigray reveal that the members are not legal experts but mainly political technocrats. There isn't any qualification requirement for membership of CIC other than the selection from and by the Woreda Council. When it comes to the competency of CCI members, it is composed of at least eight qualified legal professionals who have a strong moral standing including the Presidents and Vice

Oromia CCI law), Art. 22(1). In connection to this, the Oromia and Tigray constitutional reviewing bodies are further entrusted to dispose of non-justiciable matters. In Oromia, the CCI is entrusted to deal with the abstract cases of political nature by at least a third of members of the State Council or regional executive bodies after the law in question is enacted (posteriori review) (Id, Art. 22(4)). In Tigray, also, the power to dispose of non-justiciable mattersis handled in a different manner. The CIC render advisory opinion (consultancy service) on constitutional interpretation, consensually. This implies the Tigray system prefers resolving of constitutionality issues before the laws are enacted (priori review system). (A Proclamation Enacted to Determine the Power and Function of Tigray Regional State Constitutional Interpretation Commission, Tigray Negarit Gazette, Art. 7(2) (NO. 228/2012) (Hereinafter, Tigray CIC Law).

${ }^{1}$ The Revised Constitution of Tigray National Regional State, Art. 68, Tigray Negarit Gazette (NO. 45/2001); The Revised Constitution of Oromia National Regional State, Art. 69(2), Magalata Oromia (NO. 46/2001).

${ }^{2}$ Christophe Van Der Beken, Completing the Constitutional Architecture a Comparative Analysis of Sub-National Constitutions in Ethiopia, at 103-104 (Addis Ababa University Press, 2017)

${ }^{3}$ In ordinary court cases, Art. 17(2) of Oromia Court Re-establishment Proclamation No. 141/2008 mandates courts to assign a defense counsel, who is accused of a crime punishable by a 'rigorous sentence, not less than five years'. Similarly, Art. 6 of Tigray Regional State Courts Reestablishment Proclamation No. 243/ 2013 guarantees 'every person charged by criminal cases" has the right to request legal representation by proofing the insufficiency of means to pay for it'.

${ }^{4}$ P. Taylor v. Jamaica, Communication No. 707/1996, (Views adopted on 14 July 1997), in UN doc. GAOR, A/52/40 (vol. II), at 241, para. 8.2.

${ }^{5}$ Oromia CCI law, Supra note 67, Art. 31, A Proclamation Enacted to Establish Oromia Region Constitutional Interpretation Commission and Determine its Power and Duties, Magalata Oromia, Art. 27 (No. 167/2011). (Hereinafter, Oromia CIC law).

${ }^{6}$ Tigray CIC law, Supra note 67, Art. 31, A Proclamation Enacted to Determine the Power and Function of Tigray Regional State Council of Constitutional Inquiry, Tigray Negarit Gazette, Art.32 (NO. 229/2012) (Hereinafter, Tigray CCI Law).

${ }^{7}$ Yonatan Tesfaye, 'Judicial Review and Democracy: A Normative Discourse on the (Novel) Ethiopian Approach to Constitutional Review', 14 Afr. J. Int'l \& Comp. L. 75 (2006).

${ }^{8}$ For instance, in Romania, the judges of the Constitutional Court must have a background of extensive legal training, a high level of professional competence and experience of at least 18 years working in the legal field or in legal higher education. Similarly, the candidates for Italy's Constitutional Court must be drawn either a judge (active or retired) on one of Italy's higher Courts (ordinary or administrative) or a full professor of law or a lawyer with 20 years' experience in practice (Constitutional Review in New Democracies, Briefing paper 40, Democracy Reporting International, 2013), retrieved from http://democracy-reporting.org/files/dri-bp40enconstitutionalreview in new democracies 2013-09.pdf, last visited on 15 March 2016 
Presidents of the Regional Supreme Courts. However, since the CCI has an advisory role limited only to making their recommendation which cannot bind the CIC members who are normally the final interpreters. It can't resolve the issue of the competence deficiency in the CIC.

\subsubsection{Constitutional Interpretation Commission (CIC)}

In Oromia and Tigray, the members of CIC are not normally judges, rather they are political representatives of the electorates of district councils selected for a fixed term of five years. ${ }^{1}$ This may lead to the problem that the politicians may tend to interpret the constitution in the light of their political interests and intentions. Subsequently, this will undermine the rule of law.Institutionally in both regions, the CIC is organized under the secretariat of State Council. ${ }^{2}$ In both regions the CIC has no institutional independence since their office is organized within the secretariat of the regional legislature.

What is more, the CIC does not have financial autonomy on preparing and administering its budget. In both regions, the constitution provides that the CIC shall get the necessary secretarial and financial "support" from State Council. ${ }^{3}$ In Oromia, the budget proposal of CIC are submitted to the Caffee for approval under the budget for the secretariat of the Caffee. It requires the permission of the secretariat to utilize such budget after approval. ${ }^{4}$ In Tigray, the budget of the CIC is proposed and allocated by the State Council..$^{5}$ In doing so, the State Council has the duty to hold books and accounts that disclose such financial utilization by CIC. This implies that the State Council financially controls the acts of the CIC.

In relation to independence and impartiality on decisions, in both regions, it's difficult to think that those members are free from political influences because they represent a certain political party at district levels. In such cases, especially in politically motivated cases, there is a possibility to improperly promote the interests of one of the parties to the detriment of the other. In addition, there are no procedural provisions to guide each member on how to act impartially and to enable them consider their position in thedecision-making proceedings in the event of a conflict of interest.

In other systems, the establishment, power and function of constitutional review organs is usually provided in the Constitution. Alternatively, the organ itself issues the law to govern the detailed power and function as well as the internal structure of the organ in order to ensure independence and impartiality from political organs ${ }^{6}$. In the case of Oromia and Tigray, the CIC as a guardian of regional constitution is empowered to control legislative acts. However, the detail of the establishment, internal structure, budget, power and function of the CIC and CCI are determined by State Councils - the State legislatures. This relationship effectively puts the institution under the control of the legislatures making it difficult for each institution to act as independently as it may be expected.

\subsubsection{Council of Constitutional Inquiry (CCI)}

In Tigray Regional State the office of CIC is organized by the State Council within its own secretariat. ${ }^{7}$ On the other hand in Oromia, the law does not guarantee that the CCI will have its own office; instead, the law provides the Council to use the office of CIC to perform the task of advisory role. ${ }^{8}$ Regarding the personal independence of CCI members, eight out of eleven CCI members are all legal professionals nominated by the Regional State President, who is normally a member of the governing political party and the State Council. ${ }^{9}$ It makes it difficult to assume that the State President will be able tonominate the legal experts free of political considerations.

At this juncture, the Oromia CCI law provides some provisions to deal with the possible issues of conflict of interest. Accordingly, any member of the CCI which has any previous interest in the litigation or if they had already seen the case in another capacity, they shall not take part in the proceedings of the CCI in the case under question. ${ }^{10}$

In addition, like $\mathrm{CIC}$, the $\mathrm{CCI}$ has less financial independence. The Oromia CCI obtains its budget from the secretariat of the CIC, in which the later does not have its own budget. ${ }^{11}$ While in Tigray, like CIC, the budget is proposed and allocated by State Council. ${ }^{12}$ Comparatively, the Tigray CCI is in a better position than the Oromia

\footnotetext{
${ }^{1}$ Oromia CIC law, Supra note 72, Art. 7; Tigray CIC law, Supra note 67, Art. 6.

${ }^{2}$ Oromia CIC law, Art. 16(3); Tigray CIC law, Art. 17.

${ }^{3}$ Oromia Constitution, Supra note 68, Art. 67 (4); Tigray Constitution, Supra note 68, Art, 68 (4).

${ }^{4}$ Interview with Mr Abdi Kedir, Supra note 64.

${ }^{5}$ Tigray CIC law, Supra note 67, Art.29.

${ }^{6}$ For instance, the Italy Constitution vests the Constitutional Court with complete autonomy concerning its organizational structure, selfgovernment and financial management. The Court, like the Parliament, is vested with primary normative powers designed to structure the organization of its offices, i.e. to determine the spheres of competence, duties and responsibilities of its officials. The Court also has domestic jurisdiction over cases regarding its employees about their post and remuneration. The Court chooses its own president from among its members, usually among its senior members(Antonio Baldassarre, 'The Constitutional Court of Italy - the guarantee for its independency', Proceedings on the Role of the Constitutional Court in the Consolidation of the Rule of Law, European Commission For Democracy Through Law (Venice Commission), at 48(1994).

${ }^{7}$ See Tigray CCI law, Supra note 73, Art. 29.

${ }^{8}$ See Oromia CIC law, Supra note 72, Art. 32(1).

${ }^{9}$ See Oromia Constitution, Supra note 68, Art. 56(1), 65(1) and 68(2A-C); Tigray Constitution, Supra note 68, Art. 57(1), 66(1) and 69 (2AC).

${ }^{10}$ See Oromia CCI law, Supra note 67, Art. 28 (4-6).

${ }^{11} I d$, Art. 32.

${ }^{12}$ Tigray CCI law, Supra note 74, Art. 30.
} 
CCI since it has its own office and allocation of budget by the State Council.

\subsubsection{Security and Tenure}

Guarantees relating to security of tenure of judges or constitutional adjudicators are important requirements of independence and impartiality of tribunals/courts. This includes guarantee during appointment, removal procedures, adequate remuneration, and other conditions of service.

In Oromia and Tigray, the nomination and appointment of CCI members involves boththe legislative and executive bodies of the Regional States. ${ }^{1}$ The dismissal of the members of each body in both States are in the hand of the body who selected them. The law doesn't specify the procedures to be followed for dismissal unlike regular court judges who can be dismissed only constitutionally specified grounds. ${ }^{2}$

At this juncture, the Oromia Courts Re-establishment Proclamation No. 141/2008 gives more protection for the Presidents and Vice Presidents of the Regional Supreme Court by providing substantive grounds and specified procedures to remove them from their position. In this regard, since the appointment and removal of each President has immediate effect on their position as a Chairman and Vice Chairman of CCI which they hold ex officio, the law indirectly guarantees their security of tenure in the CCI.

However, such law has not been seen to be applied in practice yet. The ex- President and Vice President of Oromia Supreme Court, Tadele Negisho and Seid Jundi in 2012 and their successors Demoze Mame and Boja Tadese, respectively, were removed from their positions without following the legal standards of the above proclamation. ${ }^{3}$ This has a similar feature to that of the cases decided by UN Human Rights Committee between Mundyo Busyo et. al. v. Democratic Republic of Congo, in which the President of the country illegally and summarily dismissed 315 judges and public prosecutors, and later the Committee decided the act is incompatible with right to fair trial guarantees of Art. 14(1) of the ICCPR. ${ }^{4}$

\subsubsection{Immunity}

Even if the immunity of judges of courts /tribunals is not expressly required in human rights treaties, ensuring the security and tenure of members of the judiciary is one of the guarantees to protect their independence and impartiality. In Oromia and Tigray, both CIC and CCI members have no immunity on accounts of membership of each body. Among them, however, the three State Council members designated to CCI in both regions have constitutional immunity on account of their membership of the legislature. ${ }^{5}$

Also, State Council membership immunity is limited to the immunity from arrest or charge with a crime except in the case of flagrante delicto of serious crimes. Because, immunity on account of the vote s/he casts or the expression of opinion has been limited to sessions of the State Council, and it is not extended to the CCI meetings. ${ }^{6}$ Moreover, the FDRE Constitution does not guarantee immunity to any member of the State organs. They cannot raise legislative immunity as a defence in relation to offenses/faults of federal jurisdiction. ${ }^{7}$

Besides, from Tigray CIC, the representatives of three indigenous ethnic group of the region to the HOF have constitutional immunity on account of their membership of $\mathrm{HOF}^{8}$; whereas in Oromia, the Chairperson and the Vice-Chairperson of CCI have State immunity on account of their position as judges of Oromia Supreme Court. ${ }^{9}$

\subsubsection{Remuneration and Benefits}

In Tigray and Oromia, as discussed earlier, both CIC and CCI have no financial autonomy to prepare and administer their own budget. Moreover, members of each body have no permanent salary or remuneration being a member of the body. CIC members are only entitled to allowance and transportation expenses during meeting and traveling for the sake of participating at CIC meetings. ${ }^{10}$ In Oromia, the CCI lawpromises the remuneration of CCI

\footnotetext{
${ }^{1}$ Accordingly, all legally required legal professionals (8/11 members), including the Chairman (President) and Vice Chairman (Vice- President) nominated by regional President and appointed by State Council. The remaining three members of CCI nominated by Speaker of the State Council and designated by the Council. (See Art. 68 of Oromia and Art. 69 of Tigray Constitutions).

${ }^{2}$ This implies that the security and tenure of both CIC and CCI member have less than protection of regular court judges that constitutionally guaranteed with very specific grounds such as retirement age, disciplinary measures, incompetency, and grave illness. (See FDRE Constitution, Supra note 7, Art. 78(4); Oromia Constitution, Supra note 68, Art. 63(4); TigrayConstitution, Supra note 68, Art. 64(4).

${ }^{3}$ Oromia Court Re-establishment Proclamation provides the grounds and procedures of removal of the President and Vice-President from their post. The grounds of removal are consent, misbehaviour and incapacity. When the last two grounds are invoked, a special procedure is to be followed:the Speaker of the Caffee (State Council) forms a team consisting of three members of the Caffee and two Oromia Supreme Court judges for investigation. The team, then presents its finding to the Caffee. (See A Proclamation to Provide for the Re-establishment of Oromian Courts, Magalata Oromia, Art. 10, (NO. 141/2008).

${ }^{4}$ MundyoBusyo et al vs. Democratic Republic of Congo, Communication No. 933/2000, U.N. Doc. CCPR/C/ 78/D/933/2000 (2003), paras. 2.1 and 5.2, retrieved from https://www1.umn.edu/humanrts/undocs/933-2000.html, last visited on 16 April,2016. In our case, both officials are removed from Presidential status of administrative position, not from their position as judges of the court. However, arguable point is that the procedure set by the law is disregarded and the officials are summarily dismissed from such position. It is also clear that their removal will not be without any impact on their status as judges as they may lose various direct and indirect benefits that used to come with the position they vacated.

${ }^{5}$ See Oromia Constitution, Supra note 68, Art. 48(4-5); Tigray Constitution, Supra note 68, Art. 48(4-5).

${ }^{6} I d$.

${ }^{7}$ DejeneGirma, A Hand Book on the Criminal Code of Ethiopia, at 117-118 (Printed by Far East Trading P.L.C, 2013).

${ }^{8}$ FDRE Constitution, Supra note 7, Art. 63.

${ }_{9}^{9}$ Oromia Courts Re-Establishment Proclamation, Supra note 91, Art. 9.

${ }^{10}$ Oromia CIC law, Supra note 72, Art. 13(1b); Tigray CIC law, Supra note 67, Art. 12(1b).
} 
members to be determined by regulation issued by the CIC. ${ }^{1}$ However, there isn't any regulation issued yet. ${ }^{2}$ The Tigray CCI law, on the other hand,provides for the CCI members are entitled to allowance during investigation of cases as pursuant to finance law. ${ }^{3}$

Where the members are relieved of their responsibility in Oromia, all appointed legal professionals of CCI and all members of $\mathrm{CIC}$ are not entitled to the rights and benefits of out-going officials according to Proclamation161/2010. The exceptions in this regard are the Chairperson and the Vice- Chairperson of CCI and the three designated members of the Caffee to CCI. The same is true in Tigray.

\subsection{Fair and Public Hearing}

The UN Human Rights Committee notes that each party in a litigation should be given an opportunity to contest all arguments and evidence adduced by the other party. ${ }^{4}$ However, in the case of CCI and CIC proceedings such opportunity is based on the discretion of each body and is not available as of right. ${ }^{5}$ In this regard, the UN Human Rights Committee in the case between Ä̈rrelä and Näkkäläjärvi vs. Finland ruled that ensuring the equality between the parties is the fundamental duty of courts allowing equal opportunity to contest all the argument and evidence adduced by the other party. ${ }^{6}$ The failure of the Court or tribunal to provide full opportunity to each partyto challenge the submissions of the other would amount to a violation of the right to a fair trial.

Expeditiousness is also an important aspect of fairness of hearing. ${ }^{7}$ Both the Oromia and Tigray Regional CCI and CIC deviate from this principle because they work in part time and they meet occasionally. The Oromia CIC convenes once in a year and the CCI convenes once in three months except for extra-ordinary meetings. ${ }^{8}$ In Tigray, in principle, the CIC meets twice a year and the CCI meets three times per year unless special meetings are called. ${ }^{9}$ This might have a negative impact on the quality of decision because there could be a higher probability of delay of the hearing. ${ }^{10}$

In connection with the publicity of hearing, the Oromia CCI law provides the Council to handle issues at its disposal in a manner publicly transparent. Exceptionally, the Council may see cases in closed forum when it believes to do so. ${ }^{11}$ In Tigray, the CCI publicity of proceeding is treated in a different manner. Accordingly, the CCI discloses investigated cases to the public through different media channels. ${ }^{12}$ In relation to the public hearing of CIC proceeding, both the Oromia and Tigray laws are silent. However, the issue has been guided by ICCPR provision in addition to the constitutional recognition in the case of criminal charges. ${ }^{13}$

\section{The Implication of Non-conformity of Oromia and Tigray Constitutional Review Systems with the Basic Rules of Fair Trial}

The organization, composition and procedure of Oromia and Tigray constitutional review systems, as discussed above, does not fully comply with the basic rules of the right to fair trial. The Explanatory Note of the FDRE Constitution concerning the conformity between the state constitution and international agreement states:

Based on Art. 9(1) second sentence 'any law... contravenes this constitution (FDRE Constitution) shall be of no effect' implies all laws including state constitution, except this constitution, issued in this country. Accordingly, there should be no inconsistency between federal and state constitutions. Therefore, the solution to prevent the occurring of inconsistency between state constitutions and international agreements adopted or will be adopted by Ethiopia should be preventing inconsistency between state and

\footnotetext{
${ }^{1}$ Oromia CCI law, Supra note 67, Art. 14 (2).

2 Interview with Mr Abdi Kedir, Supra note 64.

${ }^{3}$ Tigray CCI law, Supra note 74, Art. 7.

${ }^{4}$ General Comment No. 32, Supra note 26, para. 13

${ }^{5}$ Oromia CCI law, Supra note 67, Art. 24; Oromia CIC law, Supra note 72, Art. 22(4). Tigray CIC, Supra note 67, Art. 22(4); Tigray CCI Law, Supra note 73, Art. 22(4).

6 Ä̈rrelä and Näkkäläjärvi vs. Finland, Communication No. 779/1997, CCPR/C/73/ D/779/ 1997, (1997), retrieved from https://www1.umn.edu/humanrts/undocs/779-1997.html, last visited on 09 April, 2016.

${ }^{7}$ General Comment No. 32, Supra note 26, para. 26.

${ }^{8}$ Oromia CIC law, Supra note 72, Art. 12; Oromia CCI law, Supra note 67, Art. 8 (2).

${ }^{9}$ Tigray CIC law, Supra note 67, Art. 11; Tigray CCI law, Supra note 73, Art. 12.

${ }^{10}$ There is no case decided by the organ yetand it is difficult to substantiate this argument. However, the delay of the cases presented before the Oromia CIC is indirectly related to the timeframe and periodical work of the body. In Oromia, the CCI can take up to 3 months to submit its recommendation to CIC (See Art. 8(1) of the Oromia CCI law) and the CIC can take up to 60 days from the day received the CCI recommendation (Art. 67(2) of the Oromia Constitution). Likewise, in Tigray, the CCI can take up to 60 days to submit its recommendation to CIC (Art. 6(4b) of Tigray CCI law) and the CIC take up to six months from the day the CCI recommendation is receivedto render final decision. There is a discrepancy here between the Tigrigna and Amharic version of Tigray Constitution regarding the maximum duration to dispose of the case by Tigray CIC. Art. 68(2) of Amharic version setsthe time for rendering its decision 60 days from the day therecommendation of CCIis received, while the Tigrigna version (the final legal Authority as per Art.109 of the Tigray Constitution) extends the time to six months. Art. 26 of Tigray CIC proclamation confirms the latter version). Accordingly, in Oromia, it takes up to five months and in Tigray, it takes up to eight months to dispose of a single case, excluding the time wasted before the case is brought to it.

${ }^{11}$ See Oromia CCI law, Supra note 67, Art. 27(3 and 4).

12 Tigray CCI law, Supra note 73, Art. 25.

${ }^{13}$ See Art. 20(1) of the FDRE Constitution and each regional constitution.
} 
this (federal) Constitution (Emphasis added). ${ }^{l}$

From this, one can easily understand that the term 'all laws' includes state constitutions that conform to the FDRE Constitution. The Constitution assumes that if state constitutions conform to federal constitution, there will not be a possibility of inconsistency with international agreements. Indeed, preventing contradiction between state and federal constitutions is a real solution to avert any discrepancy between the state and the international human rights.

Moreover, in Ethiopia state and federal constitutional review systems share many substantive and procedural issues. Hence, making state constitution conform to the federal constitution cannot solve all such inconsistency between state constitutional review and the fair trial guarantees of human rights standards since the earlier demonstrated problems of Oromia and Tigray constitutional review equallyapply to its counterpart of federal review.

Therefore, the questions need to be answered are the following. Are there any circumstances for the State Party to international human rights instrument to adopt a provision deviating from the standards of such instrument? If yes, to what extent and how they depart from such standards? If no, how the constitution reflects the will of the people? What is the implication of non-conformity to international human rights standard like ICCPR on member states? What kind of remedies provided by those human rights instruments and how much effective? Are the main issues need to be answered?

With regard to reservations, they are allowed if expressly done during the signing, ratifying, accepting, approving or acceding to a treaty. ${ }^{2}$ In the case of the ICCPR, for example, reservation to the particular clause of Art.14 may be acceptable, but a general reservation to the right to a fair trial would be incompatible with the object and purpose of the Covenant. ${ }^{3}$ It follows that the right to fair trial cannot be subject to general reservation, while the right to be entertained by competent, independent and impartial tribunal may be subject to reservation during the adoption process.

What circumstance lead to the reservation on the right to be entertained by competent, independent and impartial tribunal is also questionable? The treaty instruments like ICCPR are silent on the issue except providing the prohibition clause on the ground of refusal by other states or contrary to the objective of the treaty in question. ${ }^{4}$ The UN Human Rights Committee in this regard stated that ${ }^{6}[t]$ he requirement of competence, independence and impartiality of a tribunal in the sense of Art.14, para. 1 is an 'absolute right' that is not subject to any exception. ${ }^{5}$ However, Ethiopia neither puts a reservation on above rights during adoption of the ICCPR in 1993. Thus, the Oromia and Tigray Regional States constitutional review on their legal and institutional frameworks fall short of ICCPR standards. The justification for this drawback may be that the domestic constitution is the will of the people. But we are also required to be aware that the human rights' norms are the legal expression of the essential rights that every person is entitled to as a human being. For this reason, as all human rights are universal, indivisible, inalienable, interdependent and interrelated and the will of Ethiopian citizens are not exceptions to this. ${ }^{6}$

\section{CONCLUDING REMARKS}

The Tigray and OromiaRegional States entrusted the function of constitutional review to CIC (the final interpreter) and its advisory body, CCI. The former is composed of representatives of political electorates and the latter is composed of 11 members selected from and by the three arms of the regional governments. Human rights instruments adopted by Ethiopia, however, require any organ (including constitutional adjudication bodies) that entertains matters of judicial nature should guarantee the right to equality before courts and tribunals and the right to fair and public hearing by the competent, independent and impartial body. These conditions apply to the regional constitutional review system. Human rights instruments require member states and their sub-national governments to act in conformity to the treaty provisions unless limited by reservations. Both the FDRE and Regional

${ }^{1}$ FDRE Constitutional Explanatory Note, Unpublished, at 15 retrieved from http://www.abyssinialaw.com/ constitutions\#, last accessed on March 19, 2017 (Translation by author).

${ }^{2}$ Vienna Convention on the Law of Treaties (VCLT), 23 May 1969, United Nations, Treaty Series, vol. 1155, at 331, Art. 2 (1D), Arts.19-20, retrieved from http://www.refworld.org/docid/3ae6b3a10.html, last visited on 11 April2016; ICCPR General Comment No. 24, Issues Relating to Reservations Made upon Ratification or Accession to the Covenant or the Optional Protocols thereto, or in Relation to Declarations under Art. 41 of the Covenant, U.N. Doc.CCPR/C/21/Rev.1/Add.6 (1994), para. 8, retrieved from https://www1.umn.edu/humanrts/gencomm/hrcom24.htm, Last visited on 11 April 2016.

${ }^{3}$ General Comment No. 32, Supra note 26, para. 5; General Comment No. 24, id, para. 8.

${ }^{4}$ VCLT, Supra note 112, Art. 9; General Comment No. 24, paras. 6-9.

${ }^{5}$ General Comment No. 32, Supra note 26, para. 22. Here, it's important to distinguish between prohibition of reservation and prohibition of exception. Reservation is made during signing, ratifying, accepting, approving or acceding to a treaty and it's an agreement among countries, while exception made either on the treaty itself or by member states domestic acts after adoption of the treaty. In our case, the right to be entertained by competent, independent and impartial tribunal of Art. 14(1) of the ICCPR may be subject to reservation, but not subject to exception by domestic acts of member states.

${ }^{6}$ UN General Assembly, Vienna Declaration and Programme of Action, 12 July 1993, A/CONF.157/23, para. 5, retrieved from: http://www.refworld.org/docid/3ae6b39ec.html, last visited on 11 April2016. 
Constitutions also acknowledge the obligation to be bound by ratified treaty provisions.

The problems with regard to the Oromia and Tigray constitutional review systems relate to the competence, impartiality and independence of the reviewing organs. The procedure of appointment and removal of members of each reviewing body is laid down by the political organs of the States. The selection process is less accommodating to the diversity within the community because it is reserved for the majority indigenous ethnic groups to the exclusion of non-indigenous minority groups in each Regional State. The members do not enjoy permanent remuneration and immunity. Their removal is also based on grounds and procedures not clearly defined. There is no benefit that they are entitled to when they leave their role as members of the reviewing body. The reviewing bodies do not have financial autonomy in preparing and administering their own budget. In addition, both institutions work on part-time basis, and the CIC and CCI law of both regions does not guarantee the right to appointed legal counsel (in criminal constitutional complaint) for a person who has no sufficient means to pay for it.

Such drawbacks make the institutions not well suited for the protection of human rights. They cannot ensure access to constitutional justice. They are also exposed for political interference as the political organs of the Regional States are heavily involved in the running of the reviewing bodies.

In order to fix the problems mentioned above, there should be a strong political commitment to ensure the independence, impartiality, and competence of the reviewing bodies. They should be re-organised in such a way that they will be better positioned to guarantee the right to fair trial as provided in the relevant human rights instruments adopted by the country. Hence, more needs to be done to make the establishment, internal structure, composition, power and function of the constitutional review organs of Regional States in Ethiopia should consistent with the basic rules on the right to fair trial guaranteed in the international human rights instruments. 